\title{
HUMAN CHORIONIC GONADOTROPHIN FOLLOWING ORCHIDOPEXY FOR UNILATERAL PALPABLE UNDESCENDED TESTIS: EFFECT ON TESTICULAR VOLUME AND VASCULARITY
}

\author{
By \\ Ibrahim Mahmoud Elsayaad and Ahmed Fekry El-Deek* \\ Pediatric Surgery and Radiodiagnostics ${ }^{(*)}$ Departments; Faculty of Medicine (Damietta)
}

\begin{abstract}
Background: Cryptorchidism is a common male genital anomaly discovered at birth. Orchiopexy is the sole curative option. However, hormonal treatment has its potential role. The type and regimen of hormonal treatment is widely different.

Objective: To evaluate the effect of the use of human chorionic gonadotrophin (hCG) as an adjunctive therapy after orchiopexy.

Patients and Methods: The study included 60 boys presented with unilateral palpable undescended testis. Their ages at presentation ranged between 10 months and 6 years. All patients were subjected to history taking, clinical and radiological examination and orchiopexy. Patients were randomized into two equal groups. Randomization was done by a closed envelope that opened 2 weeks postoperatively by a nurse not included in the study. Group A received supportive hCG injection, two weeks after operation by single intramuscular injection weekly for 4 consecutive weeks. The dose was adjusted according to patient weight (<10kg received $500 \mathrm{IU} /$ week; $10-20 \mathrm{~kg}$ received $1000 \mathrm{IU} /$ week and above $20 \mathrm{~kg}$ received $1500 \mathrm{IU} /$ week). Group B received orchiopexy without postoperative hormonal support.
\end{abstract}

Results: About $88.4 \%$ of studied children were underwent orchiopexy in the first two years of life. Both groups were comparable as regard to pre-intervention hormonal profile, and testicular volume before intervention, while after the intervention, volume significantly increased in group A with good blood supply.

Conclusion: hCG postoperative supplementation for children with unilateral palpable undescended testis appears to be beneficial in subsequent outcome as expressed by increase in the size and vascularity of the testis.

Keywords: Undescended testis; Orchidopexy; Human chorionic gonadotrophin, Testicular volume.

\section{INTRODUCTION}

Cryptorchidism is defined as the nonexistence of one or both testes from the scrotum. It affects about $3 \%$ and up to $30 \%$ of full-term and premature neonates respectively. Thus, it is the most prevalent male genital anomaly recognized at birth
(Miller et al., 2009). It is essential to treat cryptorchidism to diminish the potential of cancer transformation, prevent atrophy, guard against trauma and torsion and improve fertility (Mouriquand, 2008 and Miller et al., 2009). 
The therapeutic modalities include medical treatment, which includes hormones potentially promoting testicular descent. Human chorionic gonadotrophin (hCG) and luteinizing hormone-releasing hormone are the most common 2 hormones used for the therapy of cryptorchidism. Success rates of hormonal treatment vary from 0-55 \% with hCG and from 9-78\% with LHRH (Bu et al., 2016).

Undescended testis often comprises distorted tubules, undeveloped Sertoli cells or micro-calcifications, representing testicular dysgenesis. Testicular dysgenesis syndrome may be produced by genetic conditions as well as by ecological reasons (Guminska et al., 2010).

On the other hand, it had been proposed that undescended testis (UT) had been showed to have a decreased number of germs cells at birth, and the loss had been documented to be progressive. High temperature destruct germ cells by reactive oxygen species and certain heat shock proteins that damages germ cells as well as sertoli cells (Hutson et al., 2017). Orchiopexy even if implemented as early as before one year of age may not inhibit postnatal changes in the testes (Liu and Li, 2010).

The rationale for postoperative $\mathrm{hCG}$ administration in the current work is based on the fact that, even with orchidopexy, impaired fertility was detected in $33 \%$ of unilateral cryptorchidism (Hutson et al., 2010).

The aim of the present work was to evaluate the effect of postoperative therapy with hCG in boys with unilateral palpable undescended testis on the testicular volume and vascularity.

\section{PATIENTS AND METHODS}

The present study was conducted at AlAzhar University hospital, Damietta, Egypt (Tertiary healthcare center). The protocol was discussed and approved by the Ethical Research Committee of AlAzhar University and an informed consent was obtained by guardians. The study was conducted during the period between January 2013 and January 2016. It included 60 boys presented with unilateral palpable undescended testis 38 on right side $(63.3 \%)$, and 22 on left side $(36.7 \%)$. Their ages at inclusion were between 10 months and 6 years (mean 38.06 months). Boys with ectopic testis, previous surgery for undescended testis, and previous preoperative hCG therapy were excluded from the study.

All patients were subjected to history taking, clinical and radiological examination and finally surgical orchiopexy was done. The diagnosis of undescended testicle was done clinically and by ultrasound examination. US with a high resolution transducer $(>7.5 \mathrm{MHz}$ ) was used as it offered the greatest accuracy in assessment of both testicular position and volume.

The scrotal ultrasound examinations included the scrotum and the inguinal area. Length and thickness of the testis were estimated in maximal longitudinal plane and width in axial plane. Testicular volumes were calculated by prolate ellipsoid formula: $\mathrm{V}=$ Length (L; vertical diameter) $\times$ Height or depth (thickness; antero-posterior diameter) $\times$ Width $(\mathrm{W}$; transverse diameter) x 0.52 (Hagag et al., 2017). Patients were randomized into two equal groups. Randomization was done by a closed envelope that opened 2 weeks 
postoperatively by a nurse not included in the study. Group A received small supportive dose of hCG injection, two weeks after operation by single intramuscular injection weekly for 4 consecutive weeks. The dose was adjusted according to patient weight $(<10 \mathrm{~kg}$ received $500 \mathrm{IU} /$ week, $10-20 \mathrm{~kg}$ received $1000 \mathrm{IU} /$ week and above $20 \mathrm{~kg}$ received 1500 IU/week). Group B received orchiopexy without postoperative hormonal support. Color doppler ultrasound was repeated at 3,6 months, 1 and 2 years for all boys, and testicular volumes were re-estimated and compared for both groups. The majority of patients were followed up for 2 years either by physical visit to the outpatient or by home visits to the patients. In addition, the final testicular position at two years postoperatively was documented. Serum levels of FSH, LH and testosterone were determined at baseline (before surgery) in all boys. Then, blood samples were taken $72 \mathrm{~h}$ after the last hCG injection. Blood was centrifuged and serum was stored at $20^{\circ} \mathrm{C}$ until analysis.

In patients with severe diminution of testicular size, the testicular atrophy was calculated by the testicular atrophy index (TAI), which was calculated according to the formula: TAI $=$ ((volume of contralateral (healthy) testis- volume of affected testis)/contralateral testis volume (healthy testis) x 100 and expressed as a percentage (Spinelli et al., 2014).

Statistical analysis of data: Collected data were analyzed by statistical package for social science (SPSS) version 22 (IBM®SPSS $®$ Inc., USA). Data were represented as mean \pm SD (standard deviation) or number and percentage for numerical or categorical data respectively. Student's $t$ and Chi square tests were used for comparison between groups for numerical and categorical data respectively. Paired samples $t$ test was used to compare the same variable before and at a specific point of time after intervention. For interpretation of results, $P$ value $<0.05$ was considered significant.

\section{RESULTS}

The study included 60 boys with palpable unilateral undescended testis. There was no significant difference between group A and group B as regards to patient's age $(17.96 \pm 11.03$ vs $20.10 \pm 14.68$ months respectively). About $88.4 \%$ (53/60) of studied boys underwent orchiopexy in the first two years of life. In addition, both groups were comparable as regards to body weight $(11.78 \pm 4.68$ vs $12.72 \pm 6.07 \mathrm{~kg}$ respectively), and preintervention hormonal profile. There was no significant difference between both groups as regards $\mathrm{FSH}, \mathrm{LH}$, and testosterone before intervention. However, after intervention, there were significant decreases of FSH and LH after surgical intervention in group A when compared to group B, and significant increase of testosterone in group A when compared to group B $\quad(21.33 \pm 5.19$ vs $13.52 \pm 2.42$ nmol/L respectively). Furthermore, in groups $\mathrm{A}$ and $\mathrm{B}$, there were significant decreases of LH and FSH, and significant increase of testosterone after intervention when compared to corresponding values before intervention. Finally, testicular volume before intervention revealed nonsignificant difference between both groups, while after the intervention, volume significantly increased in group A $(0.581 \pm 0.071$ vs $0.390 \pm 0.119$ respec- 
tively) with good vascularity as shown by follow up duplex study (Table 1).

As regard to postoperative follow up, there were significant increases of hydrocele formation and testicular pain in Group A when compared to group B $(16.7 \%, \quad 16.7 \%$ vs $0.0 \%$ and $0.0 \%$ respectively). On the other hand, suprapubic hair growth was reported in 3 $(10.0 \%)$ boys of group A compared to none $(0.0 \%)$ in group B. However, the difference was statistically nonsignificant. In addition, there was nonsignificant increase testicular atrophy in group B when compared to group A $(6.7 \%$ vs $0.0 \%$ respectively). On the other hand, there were statistically significant increase of diminished testicular size, and unchanged testicular size in group B when compared to group A $(26.7 \%, 36.7 \%$ vs $0.0 \%$ and $3.3 \%$ respectively). Finally, testicular re-ascent was reported in 5 patients in group B; 3 at scrotal neck and 2 at lower inguinal canal with significant increase when compared to group A ( $16.7 \%$ vs $0.0 \%$ respectively). Hydrocele and suprapubic hair growth were relieved completely without medication, while testicular pain needed non-steroidal antiinflammatory drugs. Testicular ascent needed another surgical intervention (Table 2).

Table (1): Demographic data of both groups.

\begin{tabular}{|c|c|c|c|c|}
\hline \multicolumn{2}{|c|}{ Variables $\quad$ Groups } & Group A & Group B & $P$ value \\
\hline \multicolumn{2}{|c|}{ Age (months) } & $17.96 \pm 11.03$ & $20.10 \pm 14.68$ & 0.53 \\
\hline \multirow[t]{5}{*}{ Age } & First year & $7(23.3 \%)$ & $6(20.0 \%)$ & \multirow[t]{5}{*}{0.94} \\
\hline & Second year & $20(66.7 \%)$ & $20(66.7 \%)$ & \\
\hline & Third year & $1(3.3 \%)$ & $1(3.3 \%)$ & \\
\hline & Fourth year & $1(3.3 \%)$ & $1(3.3 \%)$ & \\
\hline & Fifth or older & $1(3.3 \%)$ & $2(6.7 \%)$ & \\
\hline \multicolumn{2}{|c|}{ Weight $(\mathrm{kg})$} & $11.78 \pm 4.68$ & $12.72 \pm 6.07$ & 0.50 \\
\hline \multicolumn{2}{|c|}{ FSH before (IU/L) } & $0.844 \pm 0.318$ & $0.803 \pm 0.257$ & 0.58 \\
\hline \multicolumn{2}{|c|}{ FSH after (IU/L) } & $0.064 \pm 0.012^{\#}$ & $0.199 \pm 0.092^{\#}$ & $<0.001 *$ \\
\hline \multicolumn{2}{|c|}{ LH before (IU/L) } & $0.179 \pm 0.303$ & $0.224 \pm 0.378$ & 0.61 \\
\hline \multicolumn{2}{|c|}{ LH after (IU/L) } & $0.054 \pm 0.008^{\#}$ & $0.147 \pm 0.228^{\#}$ & $0.029 *$ \\
\hline \multicolumn{2}{|c|}{ Testosterone before (nmol/L) } & $0.289 \pm 0.082$ & $0.311 \pm 0.063$ & 0.24 \\
\hline \multicolumn{2}{|c|}{ Testosterone after (nmol/L) } & $21.33 \pm 5.19^{\$}$ & $13.52 \pm 2.42^{\$}$ & $<0.001 *$ \\
\hline \multicolumn{2}{|c|}{ Volume before $\left(\mathrm{cm}^{3}\right)$} & $0.386 \pm 0.055$ & $0.382 \pm 0.032$ & 0.85 \\
\hline \multicolumn{2}{|c|}{ Volume after $\left(\mathrm{cm}^{3}\right)$} & $0.581 \pm 0.071^{\$}$ & $0.390 \pm 0.119$ & $<0.001 *$ \\
\hline
\end{tabular}

\#: significant decrease after treatment when compared to corresponding values before treatment.

\$: significant increase after treatment when compared to corresponding values before treatment.

* = significant difference between groups. 
Table (2): Comparison between groups A and B as regard to postoperative follow up.

\begin{tabular}{|c|c|c|c|c|}
\hline \multicolumn{2}{|c|}{$\begin{array}{ll}\text { Variables } & \text { Groups } \\
\end{array}$} & Group A & Group B & $P$ value \\
\hline \multicolumn{2}{|c|}{ Hydrocele formation } & $5(16.7 \%)$ & $0(0.0 \%)$ & $0.020 *$ \\
\hline \multicolumn{2}{|c|}{ Suprapubic hair growth } & $3(10.0 \%)$ & $0(0.0 \%)$ & $0.08(\mathrm{~ns})$ \\
\hline \multicolumn{2}{|c|}{ Testicular pain } & $5(16.7 \%)$ & $0(0.0 \%)$ & $0.020 *$ \\
\hline \multicolumn{2}{|c|}{ Diminished testicular size } & $0(0.0 \%)$ & $8(26.7 \%)$ & $0.002 *$ \\
\hline \multicolumn{2}{|c|}{ Testicular atrophy } & $0(0.0 \%)$ & $2(6.7 \%)$ & $0.15(\mathrm{~ns})$ \\
\hline \multicolumn{2}{|c|}{ Unchanged testicular size } & $1(3.3 \%)$ & $11(36.7 \%)$ & $0.001 *$ \\
\hline \multirow{2}{*}{$\begin{array}{l}\text { Testicular- } \\
\text { ascent }\end{array}$} & Scrotal neck & $0(0.0 \%)$ & $3(10.0 \%)$ & \multirow[t]{2}{*}{$0.20 *$} \\
\hline & Lower inguinal canal & $0(0.0 \%)$ & $2(6.7 \%)$ & \\
\hline
\end{tabular}

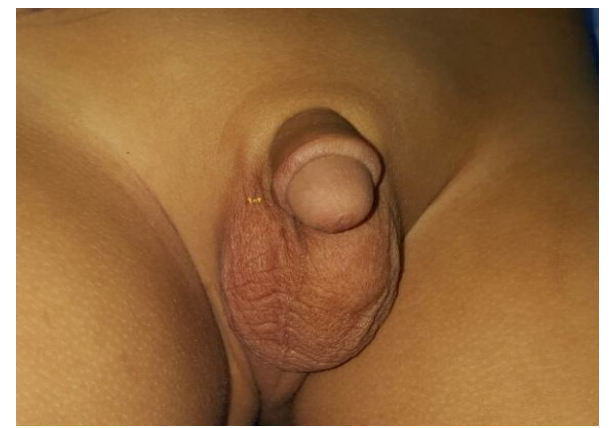

Figure (1): Preoperative right palpable undescended testis

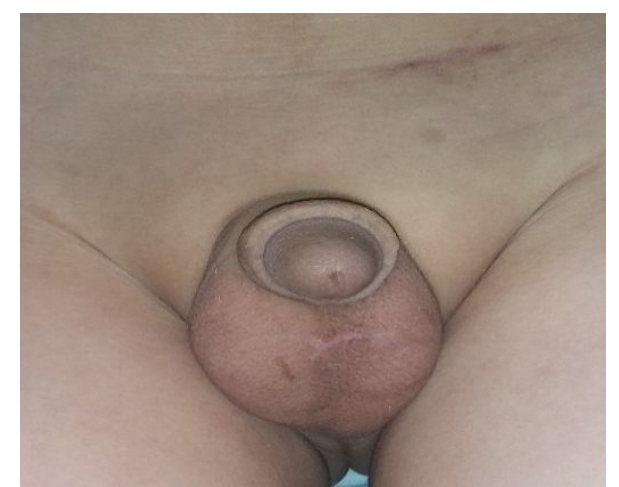

Figure (3): Left orchiopexy with hormonal therapy, 8 months postoperative with good testicular size

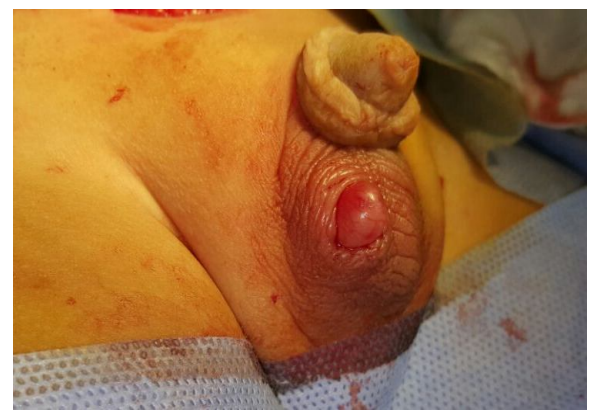

Figure (2): complete orchiopexy for right palpable undescended testis, before closure of scrotal skin

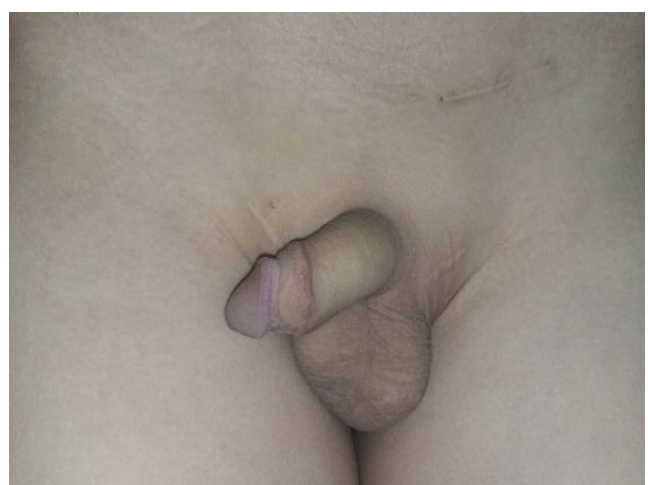

Figure (4): Left orchiopexy with hormonal therapy, 24 months postoperative with good testicular size 


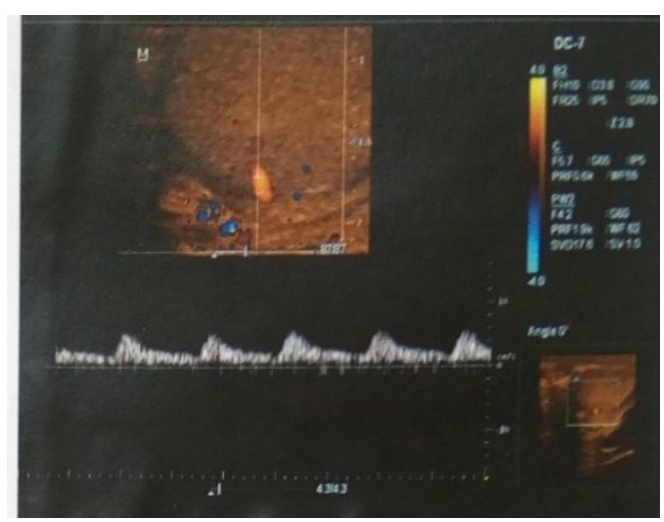

Figure (5): Postoperative Duplex ultrasound of a boy in group A, showing normal scrotal position of right testis which measures about $0.72 \mathrm{CC}$, had normal echo-pattern and normal tissue differentiation, uniform color saturation, normal biphasic Doppler flow wave of right testicular artery.

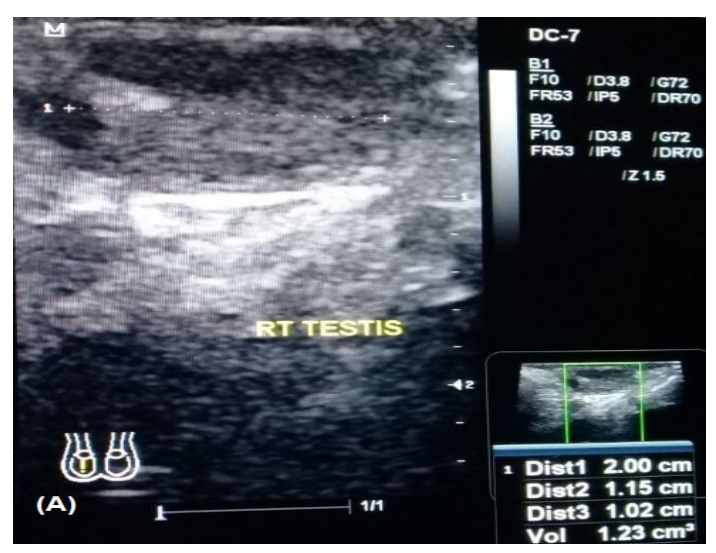

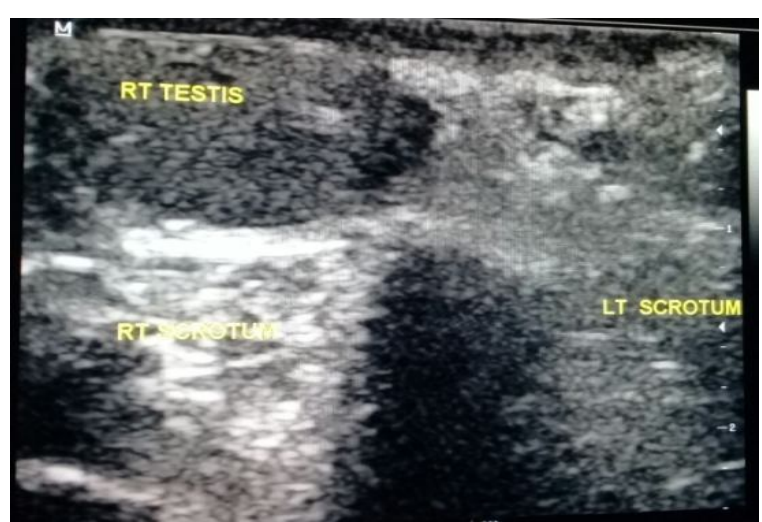

Figure (6): Empty left scrotum post orchiopexy in child with atrophic left testis

Figure (7): Ultrasound picture showing post-operative left testicular atrophy of a child 5 years old in group B.(testicular volume of Rt testis $(A)=1.23 \mathrm{~cm}^{3}, \mathrm{Lt}(\mathrm{B})=0.03$ $\mathrm{cm}^{3}$ ). Testicular atrophy index $=97.5 \%$.

\section{DISCUSSION}

The current trial was designed to assess the effect of hCG administration after orchiopexy of unilateral palpable testicle regarding volume and vasculature. The is unique in the substance used (hCG), its regimen, titration and timing of administration. However, it remains in the field of hormonal therapy with orchiopexy, the filed which is still debated. For example, European Society of Pediatric Urologists' (ESPU) advocated the use of gonadotrophin releasing hormone $(\mathrm{GnRH})$ analogues to improve fertility in boys with bilateral UT (Biers and Malone, 2010). In addition, GnRH analogues (used alone or with hCG) do 
appear to have a statistically significant beneficial effect on fertility indices both when used before (Jallouli et al., 2009) and after early surgery (Hadziselimovic, 2008). For example, Hollowell (2014) reported that, biopsies at time of orchiopexy revealed that, boys who tried hormonal therapy had greater number of germ cells than boys who had gone straight to surgery. These data led to the proposal that hormonal treatment given during childhood could possibly hasten fertility in adulthood.

On the other hand, Varela-Cives et al. (2015) reported that hormone therapy before surgery does not appear to exert any benefit on testicular volume. In addition, there were no significant differences in hormone levels between patients undergoing primary surgery and those who were operated on after hormonal treatment failure. However, they found a marked increase in testicular volume in children whose testes descended with HCG therapy alone. These data in addition to results of the present one signified the postoperative administration of hCG as an adjuvant therapy after orchiopexy.

In the present work, the majority of children $(88.4 \%)$ were treated in the first two years of life. These results were in accordance with general recommendations for the timing of orchiopexy is within the first 1.5 years of age to avoid primary histologic aberrations (Kolon et al., 2014). Otherwise, the percentage of children with UT undergoing surgery before 2 years of age increased slightly from $15.8 \%$ to $28.5 \%$ between 2001 and 2005 in Great Britain (McCabe and Kenny, 2008). Another survey from
United States of America showed that $18 \%$ of orchiopexy were done by 1 year of age, and $43 \%$ by the age of 2 (Kokorowski et al., 2010).

Oliveira et al. (2016) reported that, hCG stimulation significantly increased testosterone levels in cryptorchid children. These results are in agreement with the present work. On the other hand, VarelaCives et al. (2015) reported that FSH, LH, and testosterone levels did not show statistically significant differences.

Results of the present study revealed that the most common undesirable sequelae of hCG therapy were hydrocele formation, testicular pain and suprapubic hair growth that relieved spontaneously without medications except non-steroidal anti-inflammatory drugs for testicular pain. These results were in agreement with Niedzielski et al. (2016) who reported that momentary side-effects of hCG therapy have been detected including penile growth, pubic hair growth and groin pain.

In the present work, testicular atrophy was reported in $6.7 \%$ of boys in group B. These results were going with Kucharski and Niedzielski (2013) who reported that the most complication of orchiopexy is testicular atrophy resulting in loss of a testis. The atrophy rate was up to $8 \%$ for palpable and of up to $25 \%$ for nonpalpable testes.

In the present study, ascent of testis was reported in 5 boys $(16.7 \%)$ in group B. They underwent another surgical intervention, 6 months after the first intervention. Khirallah et al. (2015) reported that no cases presented with testicular re-ascend during the follow-up period. However, their follow up period 
was extended to 6 months only postoperatively.

In agreement with results of the present study, Niedzielski et al. (2016) reported that reoperation for testicular ascent should not be planned earlier than 6 months after the first operation.

\section{CONCLUSION}

hCG adjunctive therapy after orchiopexy for unilateral palpable undescended testis increased significantly the testicular volume and vascularity.

\section{REFERENCES}

1. Biers SM, and Malone PS (2010): A critical appraisal of the evidence for improved fertility indices in undescended testes after gonadotrophin-releasing hormone therapy and orchidopexy. J Pediatr Urol., 6:239-6.

2. Bu Q, Pan Z, Jiang S, Wang $A$ and Cheng $H$ (2016): The Effectiveness of hCG and LHRH in Boys with Cryptorchidism: A Meta-Analysis of Randomized Controlled Trials. Horm Metab Res., 48(5):318-24.

3. Guminska A, Oszukowska E, Kuzanski W, Sosnowski M, Wolski JK, WalczakJedrzejowska R, Marchlewska K, Niedzielski $\mathbf{J}$, Kula K, and Slowikowska-Hilczer J. (2010): Less advanced testicular organogenesis is associated with a higher incidence of germ cell neoplasia. Int J Androl., 33: 153-62.

4. Hadziselimovic F (2008): Successful treatment of unilateral cryptorchid boys risking infertility with LH-RH analogue. Int Braz J Urol., 34:31926.

5. Hagag AA, Erfan AA, Elrifaey SM, Gamal RM and Harakan AI (2017): Penile and Testicular Measurements in Male Neonates and Infants: Single Center Egyptian Study. Endocr Metab Immune Disord Drug Targets., 17(4):309-316.

6. Hollowell JG (2014): Undescended testis and infertility - Is hormonal therapy indicated? Transl Androl Urol., 3(4):377-81
7. Hutson JM, Balic A, Nation T and Southwell B (2010): Cryptorchidism. Semin Pediatr Surg., 19:215-24.

8. Hutson JM, Vikraman J, Li R and Thorup J (2017): Undescended testis: What paediatricians need to know. J Paediatr Child Health, 53(11):1101-1104.

9. Jallouli M, Rebai T, Abid N, Bendhaou M, Kassis M and Mhiri R (2009): Neoadjuvant gonadotropin-releasing hormone therapy before surgery and effect on fertility index in unilateral undescended testes: a prospective randomized trial. Urology, 73(6):1251-4.

10. Khirallah MG, Elafifi MA, Elbatarny AM and Elsharaby AM (2015): Orchiopexy through a single high transverse scrotal incision. Afr J Paediatr Surg., 12(1):61-5.

11. Kokorowski PJ, Routh JC, Graham DA and Nelson CP (2010): Variations in timing of surgery among boys who underwent orchidopexy for cryptorchidism. Pediatrics, 126: e576-e582.

12. Kolon TF, Herndon CD, Baker LA, Baskin LS, Baxter CG, Cheng EY, Diaz M, Lee PA, Seashore CJ, Tasian GE, and Barthold JS (2014): Evaluation and treatment of cryptorchidism: AUA guideline. J Urol., 192:337-45.

13. Kucharski $P$ and Niedzielski J (2013): Neoadjuvant human Chorionic Gonadotropin (hCG) therapy may improve the position of undescended testis: a preliminary report. Cent Eur J Urol., 66: 224-8.

14. Liu Y and Li X (2010): Molecular basis of cryptorchidism-induced infertility. Sci China Life Sci., 53(11):1274-1283.

15. McCabe JE and Kenny SE (2008): Orchidopexy for undescended testis in England: is it evidence based? J Pediatr Surg., 43:353-7.

16. Miller DC, Saigal CS and Litwin MS (2009): The demgraphic burden of urologic diseases in America. Urol Clin North Am., 36: 11-27

17. Mouriquand PD (2008): Undescended testes in children: the pediatric urologist's point of view. Eur J Endocrinal., 159: S83-S86.

18. Niedzielski JK, Oszukowska $\mathbf{E}$ and Slowikowska-Hilczer J (2016): Undescended 
testis - current trends and guidelines: a review of the literature. Arch Med Sci., 12, 3: 667-77

19. Oliveira LR, Homma TK, Woloszynek RR, Brito VN and Longui CA (2016): Gonadal response after a single-dose stimulation test with recombinant human chorionic gonadotropin (rhCG) in patients with isolated prepubertal cryptorchidism. Basic Clin Androl., 26 (13): 1-6.

20. Spinelli C, Strambi S, Busetto M, Pucci V and Bianco $F$ (2014): Effects on normalized testicular atrophy index (TAIn) in cryptorchid infants treated with GnRHa pre and postoperative vs surgery alone: a prospective randomized trial and long-term follow-up on 62 cases. Pediatr Surg Int., 30 (10):1061-1067.

21. Varela-Cives R, Méndez-Gallart R, EstevezMart?ez E, Rodriguez-Barca P, BautistaCasasnovas A, Pombo-Arias $M$ and TojoSierra R. (2015): Cross-sectional study of cryptorchidism in children: testicular volume and hormonal function at 18 years of age. Int Braz J Urol., 41: 57-66. 


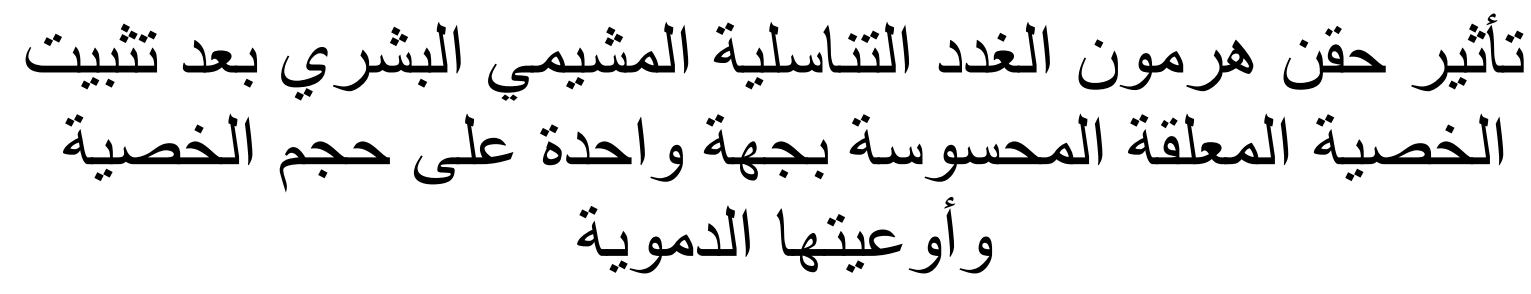

إبراهيم محمود الصياد ـ أحمد فكرى الايكث*

قسم جراحة الأطفال وقسم الأثثعة التشخيصية (*) ـ كلية الطب (دمياط ) - جامعة الأزهر

خلقية البحث: تمثل الخصية المعلقة واحدة من أكثر الأمراض الخلقية شيوعا فى الجهاز البولى

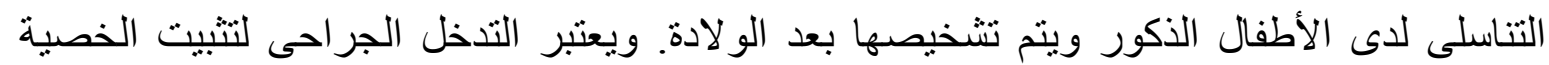
المعلقة داخل كيس الصفن هو الخيار العلاجي الأكيد. والعلاج الهرموني له دور، ولكن نوع ونئ ونظام إعطاء العلاج الهرموني يختلف بصورة كبئ لهبيرة

الهرف من البحث: تقييم إستخدام هرمون الغدد التناسلية المشيمي البشرى كعلاج مساعد بعد تثبيت الخصية المعلقة.

المرضى وطرق البحث: اشتملت الدراسة على ، آ طفلا يعانون من خصية معلقة محسوسة وبجهة

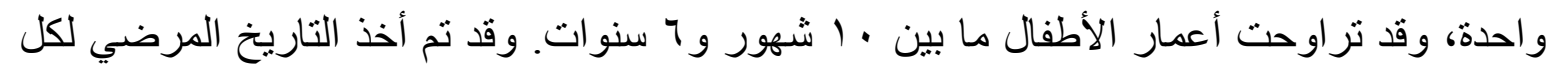

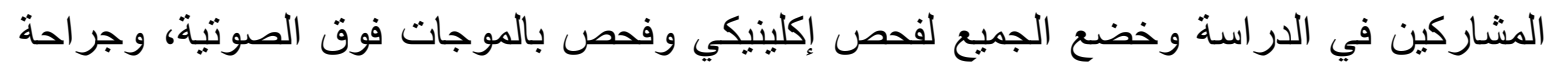
تثبيت الخصية. وتم تقسيم المرضي بصورة عشو ائية إلي مجموعتين متساويتين: المجموعة الأولى تم

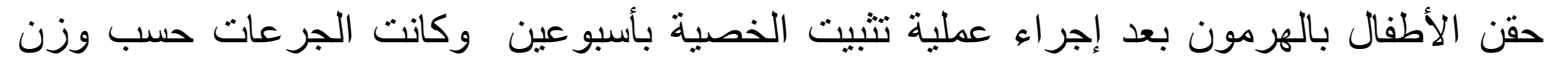

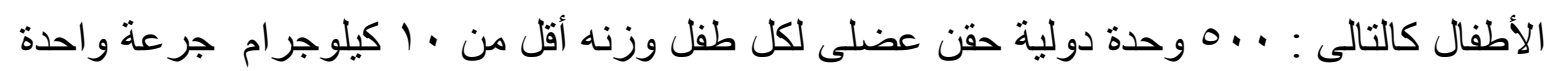

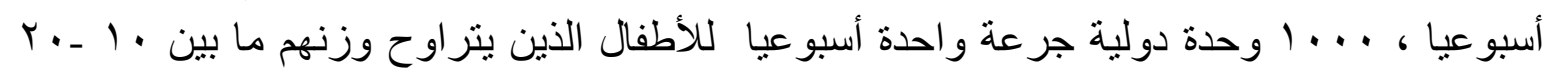

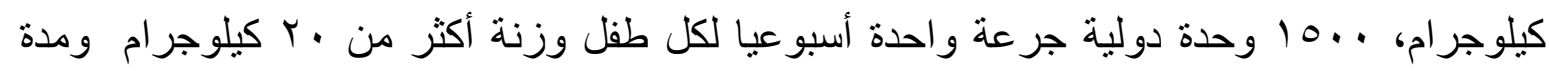

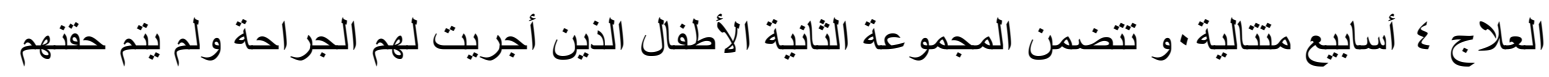

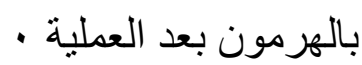

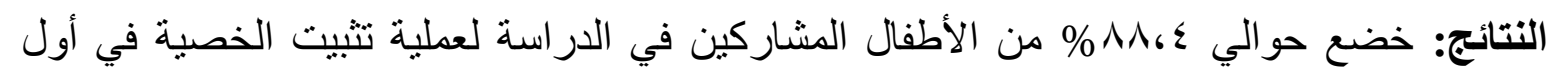
عامين من أعمار هم. ولم توجد فروق ذات دلالة إحصائية بين مجموعتي الدراسة بالنية النسبة لقياسات

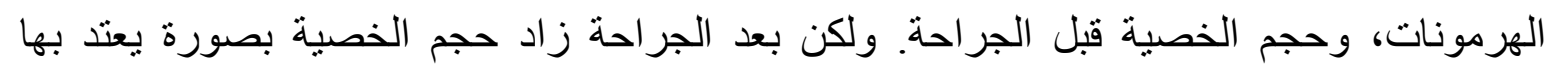
إحصائيا في المجمو عة الأولي، وكانت الزيادة في الحجم مصحوبة بتغذية دموية جيدة.

الاستتتاج: يبدو العلاج بهرمون الغدد التناسلية المشيمي البشرى بعد تثبيت الخصية المعلقة علي جهة و احدة كعلاج مفيد بالنسبة للنتائج بعد الجر احة، كما ظهر في زيادة حجم الخصية والتدفق الدموي إليها. 